CZASOPISMO INŻYNIERII LACDOWEJ, ŚRODOWISKA I ARCHITEKTURY JOURNAL OF CIVIL ENGINEERING, ENVIRONMENT AND ARCHITECTURE JCEEA, t. XXXII, z. 62 (3/I/15), lipiec-wrzesień 2015, s. 75-86

\author{
Joanna CZARNOTA ${ }^{1}$ \\ Adam MASŁOŃ ${ }^{2}$
}

\title{
ANALIZA EFEKTYWNOŚCI TECHNOLOGICZNEJ OCZYSZCZALNI ŚCIEKÓW W NISKU
}

\begin{abstract}
Przedmiotem pracy jest analiza efektowności technologicznej oczyszczalni ścieków komunalnych w Nisku (woj. podkarpackie). Mechaniczno-biologiczna oczyszczalnia ścieków została wybudowana i oddana do eksploatacji w 1997 r. Projektowa wielkość obiektu wynosi 40000 RLM, a jej przepustowość obliczeniowa wynosi $Q_{\text {śrd }}=7147 \mathrm{~m}^{3} \cdot \mathrm{d}^{-1} \mathrm{i}_{\mathrm{maxd}}=11000 \mathrm{~m}^{3} \cdot \mathrm{d}^{-1}$. Proces technologiczny opiera się na mechanicznym i biologicznym oczyszczaniu ścieków metodą osadu czynnego w rowach cyrkulacyjnych. Ciąg technologiczny oczyszczalni składa się z przepompowni głównej, komory krat schodkowych automatycznych, dwóch poziomych dwukomorowych piaskowników napowietrzanych, dwóch naprzemiennie pracujących rowów cyrkulacyjnych oraz osadnika wtórnego radialnego. Z kolei przeróbka osadów ściekowych opiera się na zagęszczaniu grawitacyjnym, odwadnianiu osadów na prasie i higienizacji osadów za pomocą wapna. W rozpatrywanym okresie w 2013 r. do obiektu dopływały ścieki w ilości ok. $4300 \mathrm{~m}^{3} \cdot \mathrm{d}^{-1}$, stanowiąc średnio ok. $60 \%$ przepustowości projektowanej. Z kolei wielkość oczyszczalni wyrażona równoważną liczbą mieszkańców kształtuje się na poziomie 7815 RLM. Jakość ścieków oczyszczonych odpowiadała warunkom określonym w pozwoleniu wodnoprawnym. Określona średnia efektywność usunięcia zanieczyszczeń ze ścieków w analizowanym okresie wyniosła odpowiednio: BZT $-97,6 \%$; ChZT $_{\text {Cr }}-91,2 \%$; $\mathrm{Z}_{\mathrm{og}}-96,0 \%, \mathrm{~N}_{\mathrm{og}}-83,1 \%$ i $\mathrm{P}_{\mathrm{og}}-86,1 \%$ i była wyższa od minimalnych stopni redukcji zanieczyszczeń dla oczyszczalni o wielkości RLM=15000 99999 określonych w Rozporządzeniu Ministra Srodowiska. Dodatkowym potwierdzeniem wysokosprawnego i niezawodnego funkcjonowania technologicznego oczyszczalni ścieków są wyznaczone wskaźniki niezawodności.
\end{abstract}

Słowa kluczowe: oczyszczanie ścieków, komory cyrkulacyjne, związki biogenne

\section{Wprowadzenie}

Ścieki komunalne, czyli wody zużyte m.in. w gospodarstwach domowych oraz na cele produkcyjne w przemyśle, mogą mieć bardzo duży wpływ na jakość naszych zasobów wodnych, w szczególności jeśli nie są właściwie oczyszczane [1]. Nieprawidłowa eksploatacja oczyszczalni ścieków powoduje wprowadzenie do

1 Joanna Czarnota, Politechnika Rzeszowska, al. Powstańców Warszawy 6, 35-959 Rzeszów, tel. 17 8651964, askalucz@prz.edu.pl

2 Autor do korespondencji/corresponding author: Adam Masłoń, Politechnika Rzeszowska, al. Powstańców Warszawy 6, 35-959 Rzeszów, tel. 17 7432407, amaslon@prz.edu.pl 
środowiska niedozwolonych ładunków zanieczyszczeń, co zazwyczaj skutkuje pogorszeniem jakości wód odbiorników ścieków (rzek, jezior) i stanu środowiska naturalnego. Następstwem tych ,działań” w dużej mierze jest ograniczenie przydatności zasobów wodnych do celów rolniczych, przemysłowych, a przede wszystkim zaopatrzenia w wodę pitną, jak również zmniejszenie walorów rekreacyjnych pobliskich terenów [2,3]. W związku z powyższym istotnym jest:

- zaprojektowanie odpowiedniego ciągu technologicznego oczyszczalni ścieków,

- prawidłowa eksploatacja zastosowanych urządzeń, co pozwoli na odprowadzenie do odbiornika ścieków o odpowiedniej jakości,

- podjęcie działań, które pozwolą na utrzymanie we właściwym stanie techniczno-eksploatacyjnym urządzeń służących do oczyszczania ścieków,

- odprowadzanie do odbiornika ścieków o parametrach nieprzekraczających wartości ustalonych w pozwoleniu wodno-prawnym,

- wykonywanie analiz ścieków dopływających do oczyszczalni oraz ścieków oczyszczonych [1].

W pracy przeprowadzono analizę efektywności oczyszczalni ścieków w Nisku w roku 2013, w oparciu o podstawowe wskaźniki zanieczyszczeń: BZT $_{5}$, $\mathrm{ChZT}_{\mathrm{Cr}}$, zawiesinę ogólną, $\mathrm{N}_{\mathrm{og}}$ i $\mathrm{P}_{\mathrm{og}}$. Dodatkowo określono dla w/w wskaźników współczynniki niezawodności, które stanowiły dodatkowe kryterium oceny pracy oczyszczalni ścieków.

\section{Charakterystyka oczyszczalni ścieków w Nisku}

Mechaniczno-biologiczna oczyszczalnia ścieków w Nisku (woj. podkarpackie) została uruchomiona w 1997 r., stanowiąc w ówczesnym okresie obiekt o wysokim standardzie wyposażenia, wysokim stopniu redukcji zanieczyszczeń oraz zautomatyzowanym procesie technologicznym. Projektowa wielkość obiektu wynosi $40000 \mathrm{RLM}$, a jej przepustowość obliczeniowa wynosi $\mathrm{Q}_{\text {srd }}=7147 \mathrm{~m}^{3} \cdot \mathrm{d}^{-1}$ i $Q_{\operatorname{maxd}}=11000 \mathrm{~m}^{3} \cdot \mathrm{d}^{-1}$. Do oczyszczalni dopływają ścieki siecią kanalizacyjną sanitarną i ogólnospławną, która obejmuje miejscowości: Nisko, Racławice i Zarzecze, jak również trafiają ścieki bytowo-gospodarcze dowożone taborem asenizacyjnym. Doprowadzane ścieki stanowią mieszaninę ścieków bytowych, przemysłowych, wód opadowych, roztopowych i infiltracyjnych. Odbiornikiem ścieków oczyszczonych zgodnie z pozwoleniem wodno-prawnym jest rzeka San w km 36+600. W ramach Krajowego Programu Oczyszczania Ścieków Komunalnych wielkość Aglomeracji Nisko została określona na poziomie 16706 RLM [4].

Proces technologiczny opiera się na mechanicznych i biologicznym oczyszczaniu ścieków metodą osadu czynnego w rowach cyrkulacyjnych (Rys. 1). Ciąg technologiczny oczyszczalni składa się z przepompowni głównej, komory krat schodkowych automatycznych, dwóch poziomych dwukomorowych piaskowników napowietrzanych, dwóch naprzemiennie pracujących rowów cyrkulacyjnych oraz osadnika wtórnego radialnego. Z kolei przeróbka osadów ściekowych opiera się na zagęszczaniu grawitacyjnym, odwadnianiu osadów na prasie i higienizacji osadów za pomocą wapna (Rys. 2). 


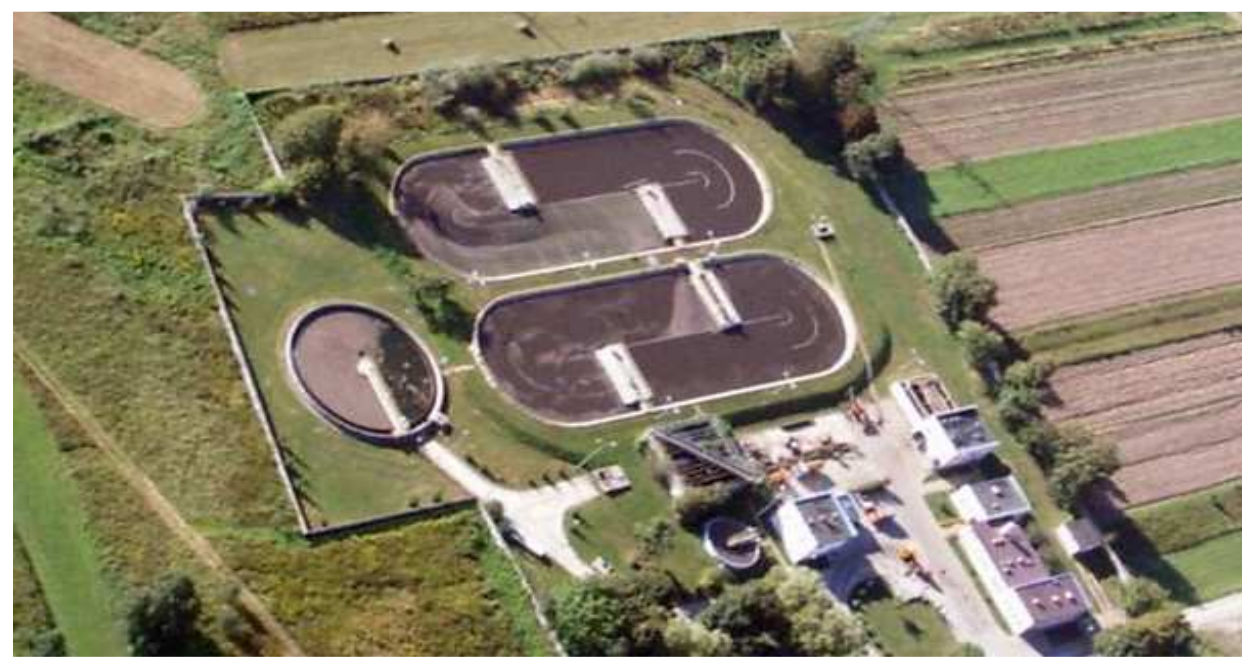

Rys. 1. Oczyszczalnia ścieków w Nisku [5]

Fig. 1. Wastewater treatment plant in Nisko [5]

W pierwszym etapie ścieki surowe dopływają do przepompowni ścieków i pompami zatapialnymi tłoczone są do kanału w budynku krat. Za pomocą automatycznych krat schodkowych następuje oddzielenie od ścieków zanieczyszczeń wleczonych i pływających w postaci skratek. Dalej ścieki przepływają do dwukomorowego napowietrzanego piaskownika poziomego wraz $\mathrm{z}$ odtłuszczaczem, gdzie następuje wytrącenie piasku oraz zatrzymanie substancji flotujących. Piasek kierowany jest do separatora piasku, skąd odcieki odprowadzane są ponownie do pompowni dopływu, a piasek trafia do kontenera. Na końcu piaskownika ścieki spływają przez przelew do części biologicznej oczyszczalni. W części biologicznej ścieki, poprzez rozdzielacz dopływu (R), doprowadzane są naprzemiennie do dwóch połączonych ze sobą rowów cyrkulacyjnych, w których mieszanie i napowietrzanie osadu czynnego zapewniają szczotki napowietrzające. Rowy cyrkulacyjne stanowią odmianę klasycznych komór osadu czynnego, którą charakteryzuje specyficzny przepływ tłokowy na granicy pełnego wymieszania. Ruch na zakolach ma złożony charakter - trójwymiarowy i posiada cechy ruchu śrubowego. Komory cyrkulacyjne osadu czynnego nazywane są również rowami oksydacyjnymi, rowami biologicznymi, komorami obiegowymi lub komorami Caroussel [6]. Biologiczne oczyszczanie prowadzone jest niskoobciążonym osadem czynnym dzięki kombinacji procesów nitryfikacji i denitryfikacji oraz biologicznej defosfatacji. Rowy cyrkulacyjne w przedmiotowej oczyszczalni wyposażone są w automatycznie regulowane przelewy dla odprowadzania osadu czynnego do jednego osadnika wtórnego radialnego, w którym następuje sedymentacja osadu czynnego i klarowanie ścieków oczyszczonych. Ścieki oczyszczone kierowane są do zbiornika wody gospodarczej (wykorzystywane częściowo do płukania instalacji odwodnienia osadu) i poprzez komorę pomiarową odprowadzane do odbiornika [4]. 


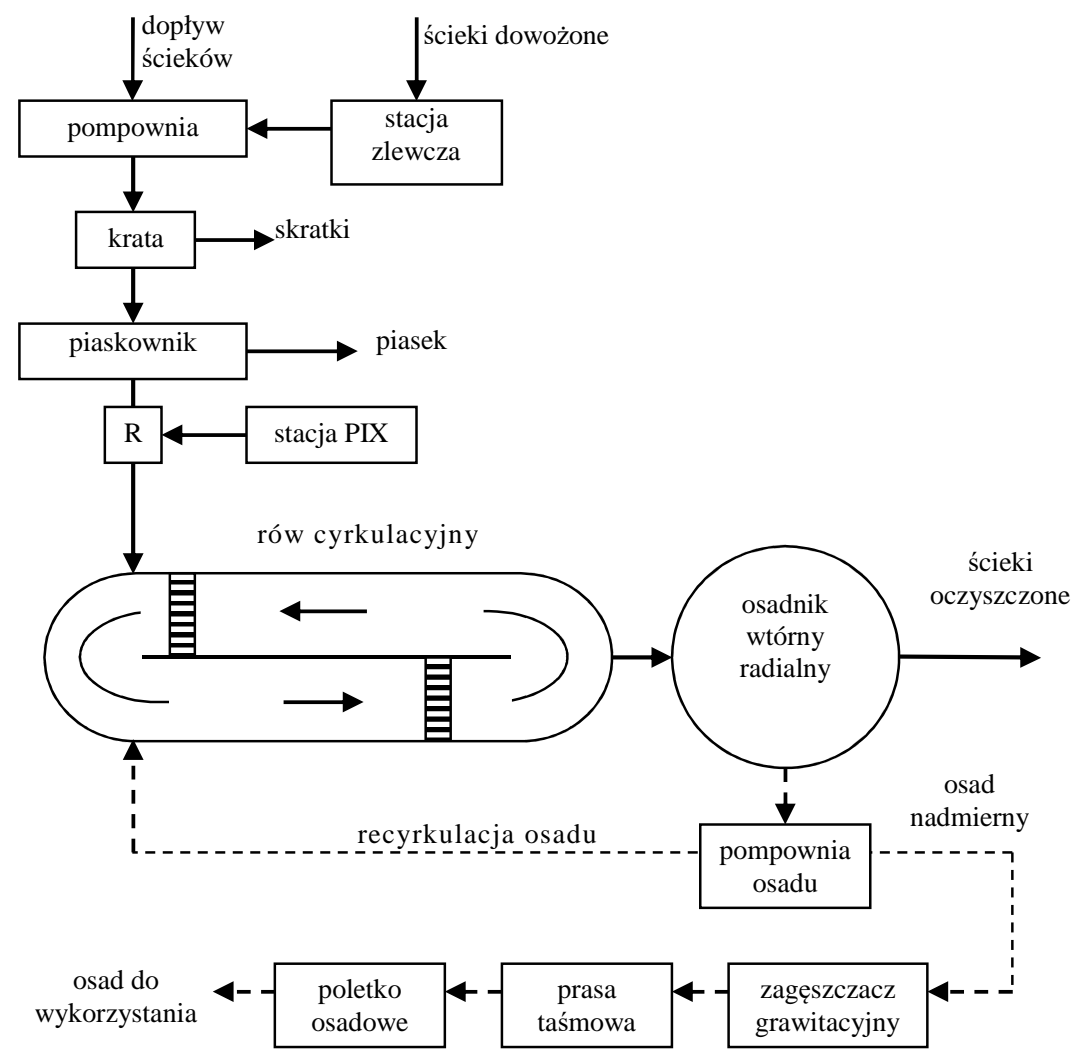

Rys. 2. Schemat technologiczny oczyszczalni ścieków w Nisku

Fig. 2. The technological scheme of the Nisko WWTP

Z kolei powstały osad nadmierny jest zagęszczany z dodatkiem koagulantu, a następnie odwadniany na prasie filtracyjnej taśmowej do ok. $20 \%$ suchej masy, higienizowany i podajnikiem ślimakowym kierowany na poletko składowania osadu. Wody nadosadowe z procesu zagęszczania oraz odcieki z odwadniania osadu doprowadzone są do kolektora głównego przed kratami. Ponadto na oczyszczalni znajduje się instalacja chemicznego strącania fosforu, która okresowo jest używana do wspomagania biologicznej redukcji fosforu. Zaprojektowano ją na wypadek przekroczenia zawartości fosforu w ściekach dopływających do oczyszczalni. PIX (40\% wodny roztwór $\mathrm{Fe}_{2}\left(\mathrm{SO}_{4}\right)_{3}$ ) dozowany jest bezpośrednio do ścieków doprowadzanych do zbiorników osadu czynnego. Powstające na oczyszczalni komunalne osady ściekowe, były dotychczas wykorzystywane między innymi do rekultywacji biologicznej zamykanego składowiska odpadów w Nisku oraz przekazywane do uprawy roślin nieprzeznaczonych do spożycia [4].

Analizę pracy obiektu przeprowadzono na podstawie wyników badań ścieków surowych i oczyszczonych z roku 2013, odpowiednio kwartalnych i miesięcznych, udostępnionych przez eksploatatora oczyszczalni [4]. Ocenę sprawności działania 
oczyszczalni oparto na wielkości zmniejszenia wskaźników zanieczyszczeń $\mathrm{BZT}_{5}$, ChZT $_{\mathrm{Cr}}$, zawiesiny ogólnej, azotu ogólnego oraz fosforu ogólnego i porównania względem wymagań prawnych w zakresie usuwania zanieczyszczeń $[7,8]$. W tabeli 1 zestawiono dopuszczalne wartości stężeń zanieczyszczeń w ściekach oczyszczonych dla analizowanej oczyszczalni ścieków. Dla wymienionych wskaźników obliczono podstawowe statystyki opisowe, takie jak: minimum, maksimum, średnia, mediana, rozstęp, odchylenie standardowe oraz współczynnik zmienności.

Tabela 1. Dopuszczalne stężenia zanieczyszczeń w ściekach oczyszczonych

Table 1. Permissible concentration of pollutants in the treated wastewater

\begin{tabular}{|c|c|c|c|c|c|}
\hline \multirow{2}{*}{$\begin{array}{l}\text { Najwyższe dopuszczalne } \\
\text { wartości zanieczyszczeń } \\
\text { w ściekach oczyszczonych }\end{array}$} & \multicolumn{5}{|c|}{ Wskaźnik zanieczyszczeń } \\
\hline & $\begin{array}{c}\text { BZT }_{5} \\
{\left[\mathbf{m g ~ O}_{2} \cdot \mathbf{d m}^{-3}\right]}\end{array}$ & $\begin{array}{c}\mathrm{ChZT}_{\mathrm{Cr}} \\
{\left[\mathrm{mg} \mathrm{O}_{2} \cdot \mathbf{d m}^{-3}\right]}\end{array}$ & $\begin{array}{c}\text { Zaw. og. } \\
{\left[\mathrm{mg} \cdot \mathbf{d m}^{-3}\right]}\end{array}$ & $\begin{array}{l}\text { Azot og. } \\
{\left[\mathrm{mg}^{\left.-\mathbf{d m}^{-3}\right]}\right.}\end{array}$ & $\begin{array}{l}\text { Fosfor og. } \\
{\left[\mathrm{mg}^{\circ} \mathbf{d m}^{-3}\right]}\end{array}$ \\
\hline $\begin{array}{l}\text { wg pozwolenia wodno- } \\
\text { prawnego [7] }\end{array}$ & 25,0 & 125,0 & 35,0 & 15,0 & 2,0 \\
\hline $\begin{array}{l}\text { wg Rozporządzenia Mini- } \\
\text { stra Środowiska [8] }\end{array}$ & 25,0 & 125,0 & 35,0 & $15,0^{*}$ & $2,0 *$ \\
\hline
\end{tabular}

* - wartości wymagane wyłącznie w ściekach wprowadzanych do jezior i ich dopływów oraz bezpośrednio do sztucznych zbiorników wodnych usytuowanych na wodach płynących.

\section{Efektywność oczyszczalni ścieków}

Na podstawie przeprowadzonej analizy obciążenia hydraulicznego stwierdza się, że miejska oczyszczalnia ścieków w Nisku, w rozpatrywanym okresie, funkcjonowała $\mathrm{w}$ zmiennych warunkach hydraulicznych, a wartości przepustowość kształtowała się na poziomie od $1358,0 \div 7143,0 \mathrm{~m}^{3} \cdot \mathrm{d}^{-1}$ (Tab. 2). Średni przepływ dobowy dla rozpatrywanego okresu wynosił $4302,08 \mathrm{~m}^{3} \cdot \mathrm{d}^{-1}$, tym samym średnie obciążenie w tym okresie stanowiło nieco ponad $60 \%$ obciążenia projektowanego, przy czym należy dodać, że ilość ścieków dopływających do oczyszczalni $\mathrm{w}$ analizowanym okresie wahała się w granicach od $19 \%$ do $99,9 \%$ przepustowości zaprojektowanej. Najwyższe wartości przepływów wystąpiły w miesiącach: marzec, kwiecień oraz listopad, co jest następstwem wystąpienia roztopów śniegu oraz intensywnych opadów (Rys. 3).

Tabela 2. Charakterystyka ilościowa ścieków dopływających do oczyszczalni w Nisku w 2013 r.

Table 2. Quantitative characteristics of the Nisko WWTP influent in 2013 year

\begin{tabular}{|l|c|}
\hline \multicolumn{1}{|c|}{$\mathbf{Q}_{\text {srd }}\left[\mathbf{m}^{\mathbf{3}} \cdot \mathbf{d}^{-\mathbf{1}}\right]$} & Wartość \\
\hline Wartość średnia & 4302,08 \\
\hline Mediana & 4464,00 \\
\hline Wartość minimalna & 1358,00 \\
\hline Wartość maksymalna & 7143,00 \\
\hline Odchylenie standardowe & 1290,60 \\
\hline Percentyl 15\% & 2838,0 \\
\hline Percentyl 85\% & 5557,4 \\
\hline Współczynnik zmienności & 0,30 \\
\hline
\end{tabular}




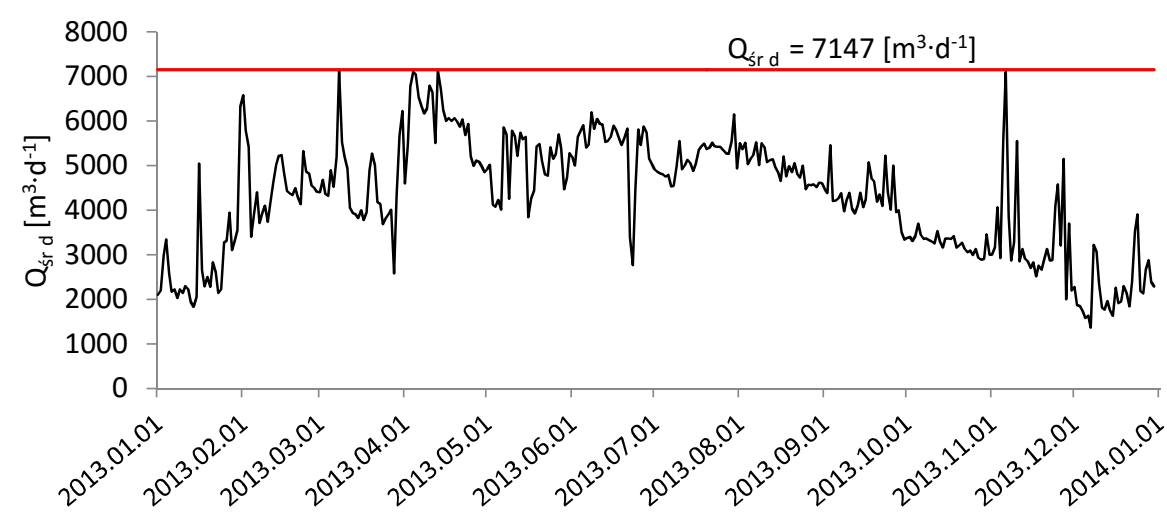

Rys. 3. Ilość ścieków doprowadzanych do oczyszczalni w 2013 r. (linią ciągłą zaznaczono projektowaną przepustowość oczyszczalni)

Fig. 3. The average daily volume of wastewater flowing into the WWTP in 2013 year

Analiza ilości ścieków dopływających na oczyszczalnię wykazała, że miesiącami o najwyższych sumarycznych przepływach były kwiecień (179178 $\mathrm{m}^{3} \cdot$ miesiąc $\left.^{-1}\right)$ oraz czerwiec $\left(162908 \mathrm{~m}^{3} \cdot\right.$ miesiąc $\left.^{-1}\right)$, zaś o najniższych styczeń $\left(85697 \mathrm{~m}^{3} \cdot\right.$ miesiąc $\left.^{-1}\right)$ i grudzień $\left(66528 \mathrm{~m}^{3} \cdot\right.$ miesiąc $\left.^{-1}\right)$. Ponadto określenie wartości średniej przepływu średniego dobowego dla każdego miesiąca oraz odchylenia standardowego umożliwiło wskazanie miesięcy (lipiec, sierpień, wrzesień, październik), które charakteryzowały małą zmiennością wielkości przepływu (Rys. 4).

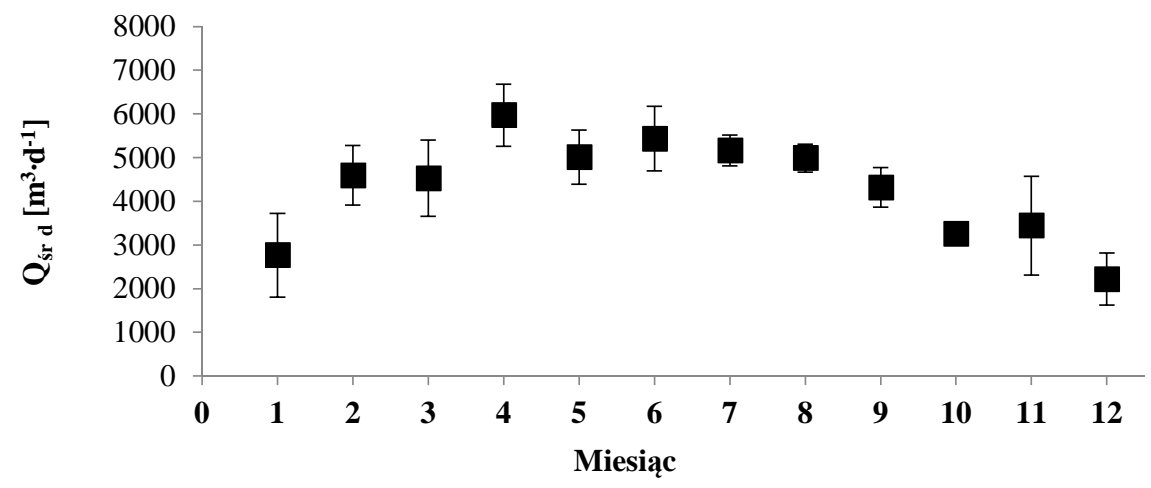

Rys. 4. Przepływ średniodobowy (wartość średnia miesięczna)

Fig. 4 . The average daily volume of wastewater (monthly average value)

Jakość ścieków surowych dopływających do oczyszczalni w Nisku, w rozpatrywanym roku, charakteryzowała się znaczącym zróżnicowaniem. Wraz ze zmianami ilościowymi widoczne były również zmiany jakościowe. Przykładowo 
w ostatnim kwartale roku odnotowano najniższą średnią wartość sumarycznego przepływu średnio-dobowego $\left(90221,0 \mathrm{~m}^{3} \cdot \mathrm{d}^{-1}\right)$ i najwyższe wartości średnie wskaźników zanieczyszczeń: $\mathrm{BZT}_{5}=180,0 \mathrm{mg} \mathrm{O} \mathrm{O}_{2} \cdot \mathrm{dm}^{-3}, \mathrm{ChZT}_{\mathrm{Cr}}=308,0 \mathrm{mg}$ $\mathrm{O}_{2} \cdot \mathrm{dm}^{-3}$, zawiesina ogólna $=87,0 \mathrm{mg} \cdot \mathrm{dm}^{-3}, \mathrm{~N}_{\mathrm{og}}=31,1 \mathrm{mg} \mathrm{N} \cdot \mathrm{dm}^{-3}$. Natomiast najniższe wartości średnie zanieczyszczeń, wynoszące odpowiednio $\mathrm{ChZT}_{\mathrm{Cr}}=$ $108,0 \mathrm{mg} \mathrm{O}{ }_{2} \cdot \mathrm{dm}^{-3}, \mathrm{~N}_{\mathrm{og}}=20,4 \mathrm{mg} \mathrm{N} \cdot \mathrm{dm}^{-3}$ oraz $\mathrm{P}_{\mathrm{og}}=2,07 \mathrm{mg} \mathrm{P} \cdot \mathrm{dm}^{-3}$, przypadały na II kwartał roku, w którym odnotowano najwyższą średnią wartość sumarycznego przepływu średnio-dobowego $\left(165800,0 \mathrm{~m}^{3} \cdot \mathrm{d}^{-1}\right)$. Analizując dane zestawione w tabeli 3 stwierdza się, że wartości $\mathrm{BZT}_{5}$ dla ścieków surowych wahały się od $32,1 \mathrm{mg} \mathrm{O}{ }_{2} \cdot \mathrm{dm}^{-3}$ do $180,0 \mathrm{mg} \mathrm{O} \mathrm{O}_{2} \cdot \mathrm{dm}^{-3}$. Rozstęp wynosił $148,8 \mathrm{mg} \mathrm{O}_{2} \cdot \mathrm{dm}^{-3}$. Wartość minimalna $\mathrm{ChZT}_{\mathrm{Cr}}$ dla ścieków surowych wynosiła $108,0 \mathrm{mg} \mathrm{O}_{2} \cdot \mathrm{dm}^{-3}$, maksymalna 308,0 $\mathrm{mg} \mathrm{O}_{2} \cdot \mathrm{dm}^{-3}$, a średnie stężenie tego wskaźnika uplasowało się na poziomie $206,8 \mathrm{mg} \mathrm{O}_{2} \cdot \mathrm{dm}^{-3}$. Wartość średnia dla zawiesiny ogólnej wynosiła $67,5 \mathrm{mg} \cdot \mathrm{dm}^{-3}$, przy minimum wynoszącym 49,0 i maksimum równym 87,0 $\mathrm{mg} \cdot \mathrm{dm}^{-3}$. W przypadku związków biogennych wartości średnie w ściekach surowych wynosiły odpowiednio $24,8 \mathrm{mg} \mathrm{N} \cdot \mathrm{dm}^{-3}$ i $3,3 \mathrm{mg} \mathrm{P} \cdot \mathrm{dm}^{-3}$. Wartości minimalne i maksymalne ukształtowały się odpowiednio na poziomie 20,4 i $31,3 \mathrm{mg}$ $\mathrm{N} \cdot \mathrm{dm}^{-3}$ dla azotu ogólnego oraz 2,1 i 4,35 $\mathrm{mg} \mathrm{P} \cdot \mathrm{dm}^{-3} \mathrm{dla}$ fosforu ogólnego. Jako uzupełnienie powyższych charakterystyk poniżej podano wartości ładunków zanieczyszczeń w ściekach dopływających do oczyszczalni. Rozkład ładunków zanieczyszczeń organicznych wyrażonych wskaźnikiem $\mathrm{BZT}_{5}$ oraz $\mathrm{ChZT}_{\mathrm{Cr}}$ kształtował się odpowiednio na poziomie od 135,1 do $583,3 \mathrm{~kg} \mathrm{O} \cdot \mathrm{d}^{-1}$ oraz od 610,7 do $1230,4 \mathrm{~kg} \mathrm{O}_{2} \cdot \mathrm{d}^{-1}$. Ładunek zawiesiny ogólnej wynosił od $223,3 \mathrm{~kg} \cdot \mathrm{d}^{-1} \mathrm{do}$ $382,2 \mathrm{~kg} \cdot \mathrm{d}^{-1}$. Natomiast zakres ładunków związków biogennych oscylował w przedziale od 89,6 do $113,5 \mathrm{~kg} \mathrm{~N} \cdot \mathrm{d}^{-1}$ oraz od 9,9 do $19,8 \mathrm{~kg} \mathrm{P} \cdot \mathrm{d}^{-1}$. Analiza danych wskazuje, że obciążenie oczyszczalni ścieków w 2013 roku wyrażone wielkością równoważnej liczby mieszkańców wynosiło 7815 RLM, co stanowi ok. $20 \%$ wielkości obliczeniowej.

Analiza wartości wskaźników zanieczyszczeń w ściekach oczyszczonych (Tab. 3) wskazuje, że średnie wielkości $\mathrm{BZT}_{5}, \mathrm{ChZT}_{\mathrm{Cr}}$, zawiesiny ogólnej, azotu ogólnego oraz fosforu ogólnego są niższe od wielkości określonych w pozwoleniu wodnoprawnym [7] oraz Rozporządzeniu Ministra Środowiska [8]. Nie odnotowano przypadków przekroczenia wymagań prawnych. Wartość średnia $\mathrm{BZT}_{5}$ w odpływie z oczyszczalni wynosiła $2,4 \mathrm{mg} \mathrm{O}_{2} \cdot \mathrm{dm}^{-3}$ i stanowiła ok. $16 \%$ wartości dopuszczalnej $\left(15 \mathrm{mg} \mathrm{O}_{2} \cdot \mathrm{dm}^{-3}\right)$. W przypadku ChZT $\mathrm{Cr}_{\mathrm{Cr}}$ wartość średnia kształtowała się na poziomie $18,2 \mathrm{mg} \mathrm{O}_{2} \cdot \mathrm{dm}^{-3}$ i była o ok. $85 \%$ niższa od wartości dopuszczalnej. Analiza współczynników zmienności dla obu wskaźników wykazała, że zarówno wartości $\mathrm{BZT}_{5}$ i ChZT $_{\mathrm{Cr}}$ charakteryzowały się większym zróżnicowaniem w przypadku ścieków oczyszczonych. Wartości średnie BZT $_{5}$ i ChZT $\mathrm{C}_{\mathrm{Cr}} \mathrm{w}$ ściekach surowych i oczyszczonych oraz efektywność ich zmniejszania w kolejnych kwartałach roku przedstawiono na Rys. 5. Stopień redukcji za nieczyszczeń dla obu wskaźników był powyżej $80 \%$, a najniższe wartości odnotowano w I kwartale zarówno dla $\mathrm{BZT}_{5}$, jak i ChZT ${ }_{\mathrm{Cr}}$. W 2013 r. stwierdzono średnią efektywność usuwania związków organicznych na poziomie 97,6\% $\left(\mathrm{BZT}_{5}\right)$ i 91,2\% $\left(\mathrm{ChZT}_{\mathrm{Cr}}\right)$. 
Tabela 3. Zestawienie statystyk opisowych wartości wskaźników zanieczyszczeń w ściekach surowych i oczyszczonych w 2013 r.

Table 3. Values of descriptive statistics parameters in raw and treated wastewater in 2013 year

\begin{tabular}{|c|c|c|c|c|c|c|c|}
\hline $\begin{array}{c}\text { Wskaźnik zanie- } \\
\text { czyszczeń } \\
\text { w ściekach }\end{array}$ & 声 & 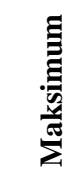 & 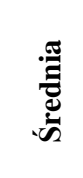 & 吾 & 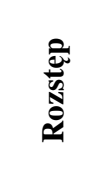 & 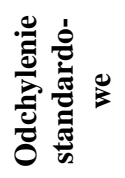 & 总 \\
\hline \multicolumn{8}{|l|}{$\begin{array}{l}\text { BZT5 } \\
{\left[\mathrm{mg} \mathrm{O}_{2} \cdot \mathbf{d m}^{-3}\right]}\end{array}$} \\
\hline ścieki surowe & 31,2 & 180,0 & 100,9 & 96,1 & 148,8 & 57,4 & 0,57 \\
\hline ścieki oczyszczone & 0,6 & 7,1 & 2,4 & 1,8 & 6,5 & 1,8 & 0,76 \\
\hline \multicolumn{8}{|l|}{$\begin{array}{l}\mathrm{ChZTCr}_{\mathrm{Cr}} \\
{\left[\mathrm{mg} \mathrm{O}_{2} \cdot \mathrm{dm}^{-3}\right]}\end{array}$} \\
\hline ścieki surowe & 108,0 & 308,0 & 206,8 & 205,5 & 200,0 & 84,2 & 0,41 \\
\hline ścieki oczyszczone & 10,0 & 45,0 & 18,2 & 18,0 & 35,0 & 9,2 & 0,51 \\
\hline \multicolumn{8}{|l|}{$\begin{array}{l}\text { Zawiesina ogólna } \\
{\left[\mathrm{mg}^{\prime} \cdot \mathbf{d m}^{-3}\right]}\end{array}$} \\
\hline ścieki surowe & 49,0 & 87,0 & 67,5 & 67,0 & 38,0 & 16,3 & 0,24 \\
\hline ścieki oczyszczone & 2,0 & 5,8 & 2,7 & 3,7 & 3,8 & 1,3 & 0,46 \\
\hline \multicolumn{8}{|l|}{$\mathbf{N}_{\mathrm{og}}\left[\mathrm{mg} \mathrm{N} \cdot \mathrm{dm}^{-3}\right]$} \\
\hline ścieki surowe & 20,4 & 31,3 & 24,8 & 23,9 & 10,7 & 3,95 & 0,16 \\
\hline ścieki oczyszczone & 0,5 & 7,5 & 4,2 & 4,2 & 7,0 & 2,1 & 0,50 \\
\hline \multicolumn{8}{|l|}{$P_{\text {og }}\left[\mathrm{mg} \mathrm{P} \cdot \mathrm{dm}^{-3}\right]$} \\
\hline ścieki surowe & 2,1 & 4,35 & 3,3 & 3,4 & 2,3 & 0,95 & 0,28 \\
\hline ścieki oczyszczone & 0,1 & 1,1 & 0,5 & 0,4 & 1,0 & 0,3 & 0,63 \\
\hline
\end{tabular}

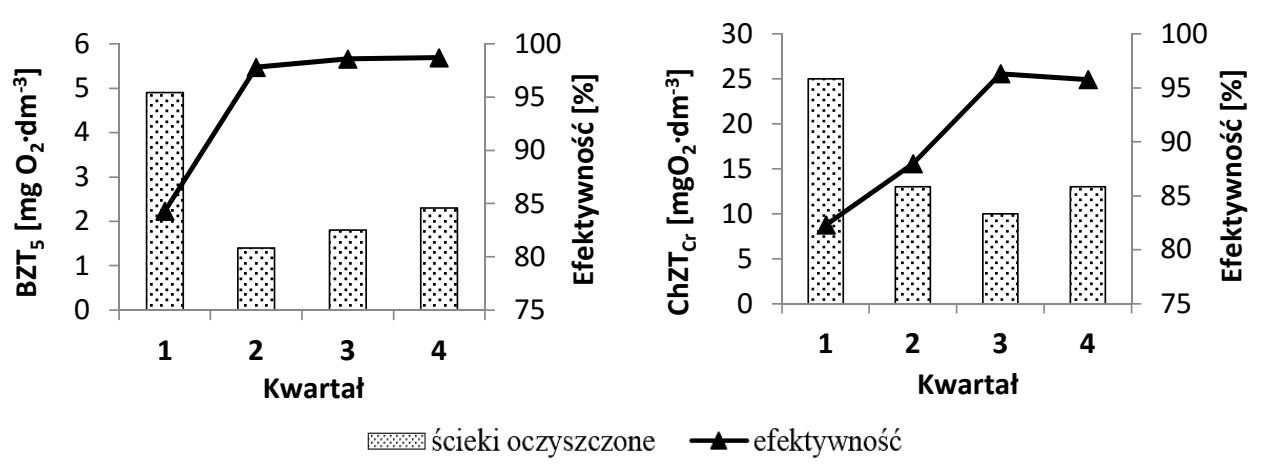

Rys. 5. Efektywność usuwania związków organicznych ze ścieków (wartości średnie kwartalne)

Fig. 5. Efficiency of organic compounds removal (quarterly average values) 
Określone ładunki zanieczyszczeń w ściekach oczyszczonych utrzymywały się w zakresie od 1,8 do $22,0 \mathrm{~kg} \mathrm{O}_{2} \cdot \mathrm{d}^{-1}$ oraz od 38,0 do $161,9 \mathrm{~kg} \mathrm{O}_{2} \cdot \mathrm{d}^{-1}$, odpowiednio w odniesieniu do $\mathrm{BZT}_{5}$ i ChZT $_{\mathrm{Cr}}$.

Średnie stężenie zawiesiny ogólnej $\left(2,73 \mathrm{mg} \cdot \mathrm{dm}^{-3}\right) \mathrm{w}$ ściekach oczyszczonych również było niższe od wartości dopuszczalnej. Efektywność usuwania zawiesiny ze ścieków nie spadła poniżej 90\%, a najniższą wartość redukcji zaobserwowano w III kwartale roku (Rys. 6). W rozpatrywanym okresie uzyskano średnią sprawność usuwania zawiesiny ogólnej na poziomie 96,0\%. Ładunki zanieczyszczeń zawiesiny ogólnej $\mathrm{w}$ ściekach oczyszczonych zmieniały się w zakresie od 6,1 do $24,9 \mathrm{~kg} \cdot \mathrm{d}^{-1}$.

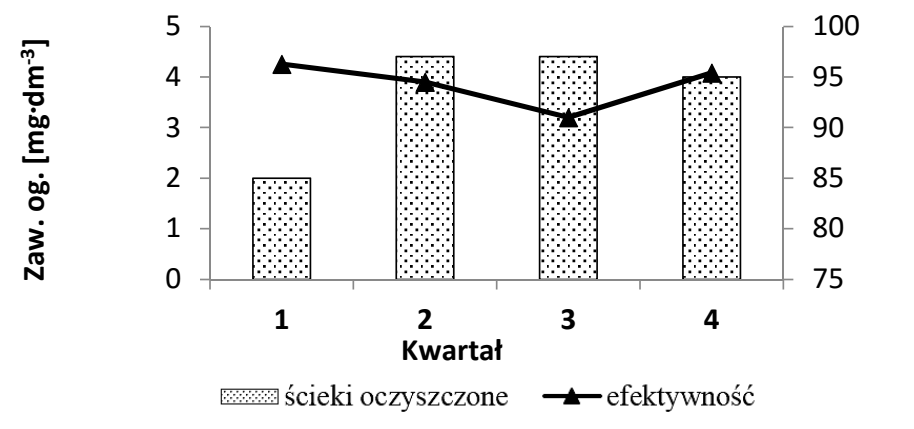

Rys. 6. Efektywność usuwania zawiesiny ogólnej (wartości średnie kwartalne)

Fig. 6. Efficiency of TSS removal (quarterly average values)

W przypadku azotu ogólnego i fosforu ogólnego średnie wartości w ściekach oczyszczonych były niższe odpowiednio o ok. $72 \%$ i $77 \%$, od wartości dopuszczalnych, które wynoszą odpowiednio $15 \mathrm{mg} \mathrm{N} \cdot \mathrm{dm}^{-3}$ i $2 \mathrm{mg} \mathrm{P} \cdot \mathrm{dm}^{-3}$. Dla ścieków oczyszczonych, w obu przypadkach, zaobserwowano wyższe współczynniki zmienności, co świadczy o większym zróżnicowaniu wartości $\mathrm{N}_{\text {og }}$ i $\mathrm{P}_{\mathrm{og}}$. Efektywność usuwania związków azotu w kolejnych kwartałach roku, z wyjątkiem I, była powyżej 80\%, natomiast w przypadku fosforu ogólnego spadek efektywności zaobserwowano w II kwartale (Rys. 7). Średnia roczna sprawność usuwania związków biogennych wyniosła $83,1 \%\left(\mathrm{~N}_{\mathrm{og}}\right)$ oraz $86,1 \%\left(\mathrm{P}_{\mathrm{og}}\right)$. W przypadku ładunków związków biogennych były to następujące wartości: 1,7 do $31,8 \mathrm{~kg}$ $\mathrm{N} \cdot \mathrm{d}^{-1}$ oraz od 0,7 do $5,5 \mathrm{~kg} \mathrm{P} \cdot \mathrm{d}^{-1}$. 


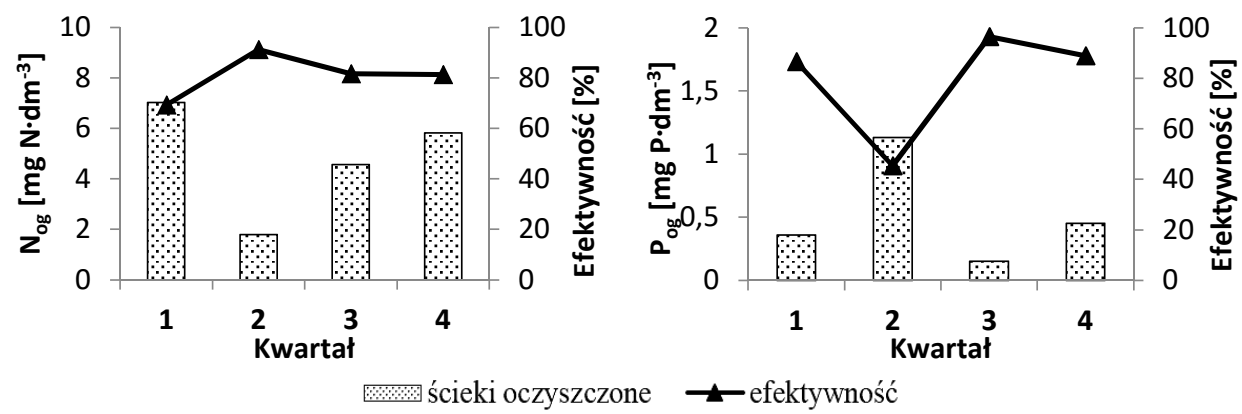

Rys. 7. Efektywność usuwania związków biogennych (wartości średnie kwartalne)

Fig. 7. Efficiency of nutrients removal (quarterly average values)

Dodatkowo w pracy oszacowano współczynniki niezawodności (WN) w odniesieniu do wymaganej jakości ścieków oczyszczonych. Określone wartości współczynników niezawodności, dla poszczególnych wskaźników zanieczyszczeń są niskie i przemawiają o prawidłowej i niezawodnej pracy oczyszczalni ścieków (Tab. 4).

Tabela 4. Wskaźniki niezawodności technologicznej oczyszczalni ścieków w Nisku

Table 4. The technological reliability indicators for the Nisko WWTP

\begin{tabular}{|c|c|c|c|c|c|}
\hline & $\begin{array}{c}\mathbf{B Z T}_{5} \\
{\left[\mathrm{mg} \mathrm{O}_{2} \cdot \mathbf{d m}^{-3}\right]}\end{array}$ & $\begin{array}{c}\mathbf{C h Z T}_{\mathrm{Cr}} \\
{\left[\mathbf{m g ~ O}_{2^{\prime}} \cdot \mathbf{d m}^{-3}\right]}\end{array}$ & $\begin{array}{l}\text { Zaw. og. } \\
{\left[\mathrm{mg}^{\left.-\mathbf{d m}^{-3}\right]}\right.}\end{array}$ & $\begin{array}{l}\text { Azot og. } \\
{\left[\mathbf{m g}^{\left.-\mathbf{d m}^{-3}\right]}\right.}\end{array}$ & $\begin{array}{l}\text { Fosfor og. } \\
{\left[\mathrm{mg}^{\left.-\mathbf{d m}^{-3}\right]}\right.}\end{array}$ \\
\hline $\begin{array}{l}\text { Wartość średnia wskaźnika } \\
\text { zanieczyszczeń w ściekach } \\
\text { oczyszczonych }\left[\mathbf{m g}^{\prime} \cdot \mathbf{d m}^{-3}\right]\end{array}$ & 2,4 & 18,2 & 2,73 & 4,18 & 0,46 \\
\hline $\begin{array}{l}\text { Dopuszczalne wartości } \\
\text { zanieczyszczeń w ściekach } \\
\text { oczyszczonych wg [7] i [8] } \\
{\left[\mathrm{mg}^{\circ} \cdot \mathrm{dm}^{-3}\right]}\end{array}$ & 25,0 & 125,0 & 35,0 & 15,0 & 2,0 \\
\hline $\begin{array}{l}\text { Współczynnik niezawodno- } \\
\text { ści (WN) }\end{array}$ & 0,1 & 0,15 & 0,08 & 0,28 & 0,23 \\
\hline
\end{tabular}

\section{Podsumowanie i wnioski}

Analiza efektywności oczyszczalni ścieków w Nisku oraz konfrontacja parametrów jakościowych ścieków oczyszczonych z wymaganiami pozwolenia wodnoprawnego pozwala wnioskować, że oczyszczalnia pracuje prawidłowo i zapewnia odpowiedni stopień usuwania zanieczyszczeń. Zastosowana w oczyszczalni ścieków w Nisku technologia oparta na metodzie niskoobciążonego osadu czynnego w komorach cyrkulacyjnych sprawdza się już od blisko 20 lat jej eksploatacji. Niewątpliwą zaletą stosowanych w niskiej oczyszczalni rowów cyrkulacyjnych jest połączenie funkcji uśredniania i oczyszczania ście- 
ków, co jest wskazane w warunkach dużej zmienności obciążenia ilościowego i jakościowego obiektu. Dzięki temu uzyskuje się stały i wyrównany odpływ ścieków oczyszczonych. Oczyszczalnie ścieków z komorami cyrkulacyjnymi posiadają zmniejszoną ilość urządzeń i uproszczoną gospodarkę osadową w porównaniu do klasycznych wielofazowych układów technologicznych.

W rozpatrywanym okresie do obiektu dopływały ścieki w ilości ok. $4300 \mathrm{~m}^{3} \cdot \mathrm{d}^{-1}$, stanowiąc średnio ok. $60 \%$ przepustowości projektowanej. Z kolei wielkość oczyszczalni wyrażona równoważną liczbą mieszkańców kształtuje się na poziomie 7815 RLM. Jakość ścieków oczyszczonych odpowiadała warunkom określonym w pozwoleniu wodnoprawnym. Określona średnia efektywność usunięcia zanieczyszczeń ze ścieków w analizowanym okresie wyniosła odpowiednio: $\mathrm{BZT}_{5}-97,6 \%$ ChZT $_{\mathrm{Cr}}-91,2 \% ; \mathrm{Z}_{\mathrm{og}}-96,0 \%, \mathrm{~N}_{\mathrm{og}}-83,1 \%$ i $\mathrm{P}_{\mathrm{og}}-86,1 \%$ i była wyższa od minimalnych stopni redukcji zanieczyszczeń dla oczyszczalni o wielkości RLM=15000 99999 określonych w Rozporządzeniu Ministra Środowiska [8]. Dodatkowym potwierdzeniem wysokosprawnego i niezawodnego funkcjonowania technologicznego oczyszczalni ścieków są wyznaczone wskaźniki niezawodności.

Analiza efektywności oczyszczalni ścieków w Nisku wskazuje, że obiekt, dla którego określono wielkość aglomeracji na poziomie 16706 RLM, jest w pełni przystosowany do nowych regulacji prawnych obowiązujących w Polsce od dnia 1 stycznia 2016 r. [9].

Mimo zadowalającej efektywności oraz poprawnej funkcjonalności i eksploatacji obiektu $\mathrm{w}$ najbliższym czasie planowana jest modernizacja i rozbudowa oczyszczalni ścieków w Nisku, która obejmować będzie niemal wszystkie urządzenia technologiczne. W strefie oczyszczania mechanicznego planowane jest wyposażenie pompowni ścieków w kratę, modernizację hali krat i dmuchaw oraz piaskownika i odtłuszczacza. W strefie oczyszczania biologicznego przewiduje się z kolei modernizację rozdzielacza dopływu, rowów cyrkulacyjnych, remont osadnika wtórnego oraz zbiornika wody gospodarczej i rurociągu odprowadzającego ścieki oczyszczone. W strefie gospodarki osadowej modernizacji zostanie poddany budynek odwadniania osadu wraz z prasą do osadu oraz zostaną przebudowane poletka do składowania osadu odwodnionego. Ponadto planuje się modernizację budynku rozdzielni elektrycznej. Planowana modernizacja usprawni jeszcze bardziej pracę oczyszczalni i pozwoli na osiągnięcie większego stopnia usuwania zanieczyszczeń ze ścieków. Wykorzystanie zalet komór cyrkulacyjnych osadu czynnego oczyszczalnia ścieków w połączeniu z nowoczesnym wyposażeniem obiektu po modernizacji zintensyfikuje efektywność oczyszczalni, a tym samym ulegnie poprawie jakość ekosystemów wodnych w obrębie zlewni dolnego Sanu.

\section{Literatura}

[1] Dyrektywa Unii Europejskiej 91/271/EWG dot. oczyszczania ścieków komunalnych.

[2] Masłoń A., Łuczyszyn J.: Analiza pracy oczyszczalni ścieków w Przemyślu po modernizacji i rozbudowie obiektu, Forum Eksploatatora, nr 5, 2011, s. 68-72. 
[3] Anders D., Wojaczek L.: Ochrona środowiska - ochrona wód. Poradnik przedsiębiorcy. Warszawa 2003.

[4] Materiały udostępnione przez Miejski Zakład Komunalny Nisko Sp. z o.o. w Nisku

[5] Portal internetowy Targeo (www.targeo.pl) [dostęp 30.04.2015 r.].

[6] Malej J.: 1999. Oczyszczanie ścieków z zastosowaniem cyrkulacyjnych komór osadu czynnego. Wybrane zagadnienia technologiczne i zasady wymiarowania. Poznań.

[7] Decyzja Starosty Niżańskiego z 23 grudnia 2005 r. z sprawie pozwolenia wodnoprawnego na odprowadzanie oczyszczonych ścieków z komunalnej oczyszczalni ścieków znajdującej się przy ul. Kościuszki 1 w Nisku, nr decyzji: OLRI.6223 - 13/05/B.

[8] Rozporządzenie Ministra Środowiska z dnia 24 lipca 2006 r. w sprawie warunków, jakie należy spełnić przy wprowadzaniu ścieków do wód lub do ziemi, oraz w sprawie substancji szczególnie szkodliwych dla środowiska wodnego (Dz. U. nr 137, poz. 984 z późn. zm.).

[9] Rozporządzenie Ministra Środowiska z dnia 18 listopada 2014 r. w sprawie warunków, jakie należy spełnić przy wprowadzaniu ścieków do wód lub do ziemi, oraz w sprawie substancji szczególnie szkodliwych dla środowiska wodnego (poz. 1800).

\title{
ANALYSIS OF TECHNOLOGICAL EFFECTIVENESS OF WASTEWATER TREATMENT PLANT IN NISKO
}

\begin{abstract}
S u m m a r y
The aim of the paper is evaluation of technological effectiveness of wastewater treatment plant in Nisko (Podkarpackie Province). The mechanical-biological wastewater treatment plant was built in 1997 year. The calculated average daily capacity is $Q_{s i r d}=7147 \mathrm{~m}^{3} \cdot \mathrm{d}^{-1}, \mathrm{Q}_{\mathrm{dmax}}=11000 \mathrm{~m}^{3} \cdot \mathrm{d}^{-1}$ and 40000 PE. The technological process involves mechanical-biological treatment of wastewater based on a circulating activated sludge tanks. Technological line consists of main wastewater pumping station, automatic grating chamber, two double-chamber horizontal aerated grit chambers, two working alternately circulation tanks and radial secondary settling tank. The sludge treatment is based on gravity thickening, dewatering of sludge on the press and hygienisation of sludge using the lime. In 2013 year the average flow of raw wastewater amounted $4300 \mathrm{~m}^{3} \cdot \mathrm{d}^{-1}$ representing average of approx. $60 \%$ of the designed capacity. The size of wastewater treatment plant expressed as equivalent number of inhabitants amounted $7815 \mathrm{PE}$. The quality of wastewater effluent meet the conditions laid down in the water-legal permit. The average efficiency of pollutants removal in WWTP in Nisko was: $\mathrm{BOD}_{5}-97,6 \%$; COD $-91,2 \%$; TSS $-96,0 \%$, TN $-83,1 \%$ and TP $-86,1 \%$ and was higher than the minimum levels of pollutions reduction for wastewater treatment plant of size $\mathrm{PE}=$ $15000 \div 99999$ defined in the Regulation of the Minister of Environment. Designated reliability indicators confirm high performance of wastewater treatment plant in Nisko.
\end{abstract}

Keywords: wastewater treatment, circulating activated sludge tank, nutrient pollution

Przestano do redakcji: 30.05 .2015 r.

Przyjęto do druku: 30.10 .2015 r.

DOI: $10.7862 / \mathrm{rb} .2015 .96$ 